\title{
Obituary
}

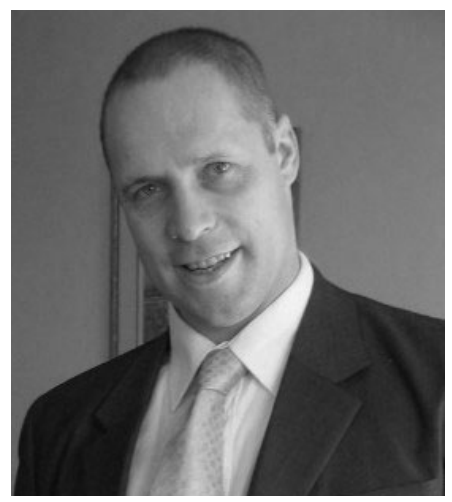

\section{Dr Tony Hall}

It is with great sadness that we report that Dr Tony Hall, after a long illness, passed away at his home in Louth, Lincolnshire on 17th March 2009. The words below have been put together by friends and colleagues as a tribute to him.

Upon leaving secondary education at Ackworth School in West Yorkshire, Tony started his higher education studying Agriculture at Newcastle University. After completing his undergraduate degree, and with a thirst for applying academic knowledge to practical industry challenges that was to become a trademark of much of his work, he did his PhD with Professor Bill Hill at Edinburgh University's Institute for Cell, Animal and Population Biology. His thesis was an analysis of food intake patterns in growing pigs from electronic feeding stations (FIRE feeders) in the sire line nucleus of the Cotswold Pig Development Company. It was a difficult analysis with some interesting and novel twists. Characteristically, Tony managed to shed the complications and draw simple practical conclusions. As well as the $\mathrm{PhD}$ he maintained an active life away from the computer, playing rugby union for Boroughmuir 2nd and 3rd XVs, regularly beating students and lecturers at squash, and playing dreadful golf - all whilst enjoying trekking and international travel with his future wife Kelly and always making an excellent companion for all of those seeking to enjoy a sociable drink in any of Edinburgh's' many hostelries.

Once the PhD study was complete it was logical for Tony, by now a world authority on performance testing, to join the small genetics group at Cotswold's headquarters at Rothwell in Lincolnshire. There his talents really blossomed. Everyone warmed to him, and he had a gift for explaining the complexities of genetic improvement in simple practical terms at all levels.

Tony quickly built a rapport with the staff on the all-important nucleus farms, and took responsibility for practical implementation of genetic improvement. Customers loved his clear and succinct explanations, and he became the mainstay of sales presentations at home and abroad. When Cotswold signed a research agreement with London University's Wye (later Imperial) College in Kent, Tony took charge of planning and executing a highly complex set of trials at the jointly operated research farm. He grew so much in his Cotswold role; he learned continuously, and he contributed enormously to the business. He was undoubtedly of managing director calibre with a great career ahead of him.

In September 2002 Tony joined Cherry Valley Farms Ltd from the Cotswold Pig Breeding Co. as Company Geneticist and early in 2004, now as Chief Geneticist, took over responsibility for the company's Pekin meat-type duck UK primary breeding operation. He very quickly put in place significant contributions in the areas of pedigree data storage and manipulation, changes to reproductive trait work and, under 


\section{Obituary}

the aegis of the company's membership of Genesis Faraday, a number of Pekin duck molecular genetics projects. He also initiated important steps in staff training within the Genetics Department. His communication and presentation skills were well known and his contribution to a range of aspects of duck breeding and genetics at a range of conferences was considerable. Tony's calm, down-to-earth manner, technical rigour and approachability quickly won him the respect of colleagues throughout Cherry Valley and beyond. He will always be remembered in academia as a pioneer and exemplar of academic-industrial interactions. Always on the look out for a new opportunity he was marked by his no-nonsense attitude and his "can-do" ethic. No problem was insurmountable.

During his time in Lincolnshire, Tony continued his rugby with Market Rasen 1st XV until his medical condition prevented him from doing so.

In a move typical of his attitude he quickly replaced playing with coaching to enable himself to have an impact on the team performance despite his enforced retirement from playing.

Tony's warmth, kindness, diplomacy and sense of fun were an inspiration to all those around him. His passing is a sad, irreplaceable loss has left a very real hole in the working life of all of his colleagues and friends. He is sorely missed.

Tony is survived by his wife Kelly and three year old daughter Caitlin who are in the thoughts of his many friends and colleagues. 